
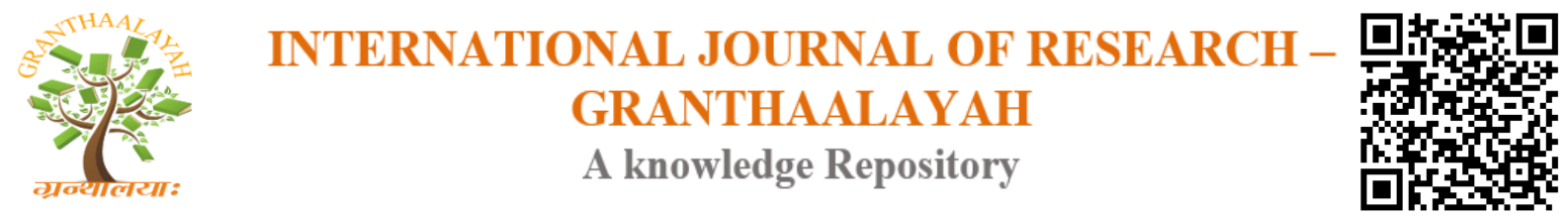

Science

\title{
UTILIZATION OF PLANT GROWTH PROMOTING RHIZOBACTERIA (PGPR) IN DISEASE CONTROL IMPORTANT IN PLANTS ONION (ALLIUM ASCALONICUM L.)
}

\author{
Francisco Fernandes *1, Abdul Latief Abadi ${ }^{2}$, Luqman Qurata Aini ${ }^{2}$ \\ ${ }^{* 1}$ Graduate School, Faculty of Agricultural, University of Brawijaya, Malang, Indonesia \\ ${ }^{2}$ Lecturer, Agricultural, University of Brawijaya, Malang, Indonesia
}

\begin{abstract}
Red onion (Allium ascalonicum L.) is one of many horticultural crops consumed by humans as a mixture of spices. For household consumption of about 635700 tonnes, non-household consumption such as the manufacturing industry amounted to 719200 tonnes, the sum total of 1.35 million meaning that the deficit for the onion. The purpose of this study was to gain insight about PGPR in increasing the growth and yield of onion, PGPR role in controlling the disease in onions, PGPR concentration in controlling the disease in onions and certain PGPR concentration in the application to control diseases in onion. Using a randomized block design (RAK) factorial $5 \times 3$ and repeated 3 times. The first factor is the concentration of PGPR with 5 levels ie: p0 (control), P1 (5 ml / liter of water / 2 plants), P2 (10 ml / liter of water / 2 plants), P3 (15 ml / liter of water / 2 plants) and P4 (20 ml / liter of water / 2 plants) and the second factor is the interval provision of PGPR with 3 levels namely: I1 (1 week, 1 x application until the age of 60 days, I2 (2 weeks, $1 \mathrm{x}$ application until the age of 60 day) and I3 (3 weeks, $1 \mathrm{x}$ application until the age of 60 days). the results showed that the onion crop by PGPR could increase plant height $(21,67 \mathrm{~cm})$, number of leaves $(32.70 \mathrm{~cm})$, the number of tubers per plant $(17.69 \mathrm{~g})$, the wet weight of tuber per plot highs $(3460.00 \mathrm{~g})$ and dry weight of tuber per plot $(3010.20 \mathrm{~g})$. the provision of PGPR can control fusarium wilt on the red onion. the higher concentration of PGPR with intervals of 3 weeks administration can suppress disease. fusarium wilt PGPR concentration of $20 \mathrm{ml} /$ liter of water with intervals of 3 weeks administration can suppress disease attacks fusarium wilt the lowest $(5.22 \%)$.
\end{abstract}

Keywords: PGPR; Diseases of the Onion.

Cite This Article: Francisco Fernandes, Abdul Latief Abadi, and Luqman Qurata Aini. (2018). "UTILIZATION OF PLANT GROWTH PROMOTING RHIZOBACTERIA (PGPR) IN DISEASE CONTROL IMPORTANT IN PLANTS ONION (ALLIUM ASCALONICUM L.)." International Journal of Research - Granthaalayah, 6(1), 126-136. https:// doi.org/10.29121/granthaalayah.v6.i1.2018.1601. 


\section{Introduction}

Red Onion (Alliums calonicum L.) is one of many horticultural crops consumed by humans as a mixture of spices. As seasoning shallots are also sold in the form of processed products such as extracts of onion, powder, essential oils, fried onions even as medicine for lowering cholesterol, blood sugar, prevent blood clots, lower blood pressure and improving blood flow (Istina, 2016), As many horticultural commodities consumed by the public, the potential for the development of the onion is still wide open not only for the domestic but also overseas (Suriani, 2012).

In 2013, although the national production of onion has been excessive (Rusono et al., 2013), but productivity is still low (10:22 tons/ha) compared to the potential that they may reach up to 20 tonnes/hectare, in 2015 productivity is still low 10.60 ton ha (BPS 2014). In general, red onion suitable to be planted in the lowlands and some are cultivated in the highlands. The Central Statistics Agency (BPS) recorded production of horticultural crops of onions throughout 20142016, red onion for household consumption of about 635700 tonnes, non-household consumption such as the manufacturing industry amounted to 719200 tonnes, the sum total of 1.35 million meaning that the deficit for the onion.

Diseases that normally occur in onion plants including root rot disease caused by Fusarium oxysporum f. sp. Cepae, anthracnose diseases caused by fungi Colletotrichum gloesporiodes and purple or total spot disease caused by the fungus Alternaria pores. The third attack this disease usually at the age of 0-35 HST (Isniah and Widodo, 2015).

Control of the disease in onion plants caused by the fungus, Fusariummildew Colletotricum gloesporiodes, and fungus Alternariaporri,it is generally recommended is a physical or chemical treatment and the use of resistant varieties. Some resistant varieties are already known to be an alternative to the control of this disease in Iran (Esfahani et al., 2012). Chemically, the use of sodium fluoride and sodium metabisulfite can suppress the development of pathogens by treatment of the embedding medium (Turkkan and Erper, 2014).

PGPR is an aggressive group of beneficial bacteria menkolonisasi rhizosphere. Activities PGPR benefit for plant growth because of its ability to provide and mobilize or facilitate the absorption of various nutrients in the soil as well as synthesize and changing the concentration of various fitohormon spur growth and can suppress the activity of a pathogen by producing various compounds or metabolites such as antibiotics and siderophore (Rosyidah et al., 2013). Choiruddin. (2010), indicates that the application of the formulation rhizobacteria indigenous on the seed followed at ages 2 and 4 WAP effectively control fusarium wilt more than $60 \%$ and increase the production of tomato plants.

\section{Materials and Methods}

This study was conducted from August to October 2017, located in the garden farmer in the village Donowarih Karangploso subdistrict, Malang, East Java, Indonesia. The village is geographically located on the plains Donowarih medium with an altitude of $\pm 700 \mathrm{~m}$ above sea level and the average temperature - average at $22^{\circ} \mathrm{C}$. 


\subsection{Samples}

The material used in this study include red onion seed tuber varieties Kramat 1, PGPR, organic fertilizers (chicken manure), manure namely inorganic fertilizer P (SP-36) with a dose of 200$250 \mathrm{~kg} / \mathrm{ha}(70-90 \mathrm{~kg} \mathrm{P} 2 \mathrm{O} 5 / \mathrm{ha}$, as much as $150-200 \mathrm{~kg} \mathrm{~N} / \mathrm{ha}$ and $\mathrm{K}$ as much as $50-100 \mathrm{~kg}$ $\mathrm{K} 2 \mathrm{O} /$ ha or $100-200 \mathrm{~kg}$ of $\mathrm{KCl} / \mathrm{ha}$.

\subsection{Research Design}

This study used a randomized block design (RAK) factorial $5 \times 3$ and repeated 3 times. the first factor is the concentration of PGPR with 5 levels ie: P0 (control), P1 (5 ml / liter of water), P2 ( $10 \mathrm{ml} /$ liter of water), P3 (15 ml / liter of water) and P4 (20 ml / liter of water) and the second factor is the interval provision of PGPR with 3 levels namely: I1 (1 week, I2 (2 weeks,) and I3 (3 weeks).

\subsection{Statistical Analysis}

The analysis of data was facilitated by the 2010 version of Microsoft Excel using analysis of variance (F-test with a 5\% standard error) Followed by a least significant difference (LSD) approach.

\section{Results and Discussion}

\subsection{Results}

Treatment concentration of PGPR with intervals of administration showing the interaction of the high (Table 1), the number of leaves (Table 2), the results of onion bulbs per panicle (Figure 1), the wet weight of tuber per plot (Figure 2), Weight dried tubers per plot (Figure 3), under a red bulb Results per hectare (Figure 4), attack percentage Disease FusariumI Wilt (Figure 5).

Table 1: High Concentration Treatment Plant Onions Due PGPR By Giving Time Interval At Age 4 WAP, 6 WAP, 8 WAP and 10 WAP.

\begin{tabular}{|l|l|l|l|l|}
\hline \multirow{2}{*}{ Perlakuaan } & \multicolumn{4}{|c|}{ Tinggi Tanaman $(\mathbf{c m})$} \\
\cline { 2 - 5 } P0I1 & $4 \mathrm{WAP}$ & $6 \mathrm{WAP}$ & $8 \mathrm{WAP}$ & $10 \mathrm{WAP}$ \\
\hline P0I2 & $17,44 \mathrm{~b}$ & $26,01 \mathrm{a}$ & $29,06 \mathrm{~b}$ & $29,74 \mathrm{bc}$ \\
\hline P0I3 & $18,17 \mathrm{cde}$ & $27,40 \mathrm{c}$ & $30,63 \mathrm{fg}$ & $30,77 \mathrm{efg}$ \\
\hline P1I1 & $16,38 \mathrm{a}$ & $30,22 \mathrm{ijk}$ & $32,82 \mathrm{no}$ & $32,88 \mathrm{~m}$ \\
\hline P1I2 & $19,88 \mathrm{hi}$ & $26,70 \mathrm{~b}$ & $28,31 \mathrm{a}$ & $28,35 \mathrm{a}$ \\
\hline P1I3 & $18,61 \mathrm{fg}$ & $28,29 \mathrm{e}$ & $30,19 \mathrm{ef}$ & $30,21 \mathrm{~d}$ \\
\hline P2I1 & $18,57 \mathrm{efg}$ & $30,28 \mathrm{jk}$ & $32,00 \mathrm{klm}$ & $32,15 \mathrm{jkl}$ \\
\hline P2I2 & $20,41 \mathrm{ijklm}$ & $28,24 \mathrm{de}$ & $29,89 \mathrm{de}$ & $29,92 \mathrm{~cd}$ \\
\hline P2I3 & $19,00 \mathrm{~g}$ & $29,92 \mathrm{ghij}$ & $31,52 \mathrm{hij}$ & $31,57 \mathrm{hi}$ \\
\hline P3I1 & $18,35 \mathrm{de}$ & $30,42 \mathrm{k}$ & $32,44 \mathrm{mn}$ & $32,50 \mathrm{~lm}$ \\
\hline P3I2 & $20,81 \mathrm{jklmn}$ & $29,75 \mathrm{efg}$ & $30,79 \mathrm{~g}$ & $30,86 \mathrm{fg}$ \\
\hline P3I3 & $20,99 \mathrm{mno}$ & 30,931 & $31,70 \mathrm{jk}$ & $31,72 \mathrm{ij}$ \\
\hline
\end{tabular}




\begin{tabular}{|l|l|l|l|l|}
\hline P4I1 & $20,82 \mathrm{klmno}$ & $29,95 \mathrm{hij}$ & $29,80 \mathrm{cde}$ & $31,02 \mathrm{~g}$ \\
\hline P4I2 & 21,38 no & $31,67 \mathrm{no}$ & $31,53 \mathrm{ij}$ & $33,65 \mathrm{n}$ \\
\hline P4I3 & $21,67 \mathrm{o}$ & $32,95 \mathrm{o}$ & $32,86 \mathrm{o}$ & $34,74 \mathrm{o}$ \\
\hline LSD & $\mathbf{0 , 5 8}$ & $\mathbf{0 , 4 5}$ & $\mathbf{0 , 4 6}$ & $\mathbf{0 , 4 6}$ \\
\hline
\end{tabular}

Description: Numbers are accompanied by the same letters in the same column are not significantly different shows based on LSD 5\%; $\mathrm{cm}=$ centimeter, $\mathrm{WAP}=$ weeks after planting. $\mathrm{P} 0=$ control; $\mathrm{P} 1=5 \mathrm{ml} / \mathrm{l} ; \mathrm{P} 2=10 \mathrm{ml} / \mathrm{l} ; \mathrm{P} 3=15 \mathrm{ml} / \mathrm{l} ; \mathrm{P} 4=20 \mathrm{ml} / \mathrm{l} ; \mathrm{I} 1=$ one application once a week; I2 = Two weeks once application; I $3=$ Three weeks once application.

Table 2: Number of Leek Due PGPR concentration Treatment With Giving Time Interval At Age 4 WAP, WAP 6, 8 and 10 WAP WAP.

\begin{tabular}{|l|l|l|l|l|}
\hline \multirow{2}{*}{ Perlakuaan } & \multicolumn{4}{|c|}{ Jumlah Daun (helai) } \\
\cline { 2 - 5 } P0I1 & $4 \mathrm{WAP}$ & $6 \mathrm{WAP}$ & $8 \mathrm{WAP}$ & $10 \mathrm{WAP}$ \\
\hline P0I2 & $21,92 \mathrm{a}$ & $30,59 \mathrm{a}$ & $35,26 \mathrm{bc}$ & $35,29 \mathrm{a}$ \\
\hline P0I3 & $21,74 \mathrm{a}$ & $31,72 \mathrm{bc}$ & $36,0 \mathrm{c} \mathrm{c}$ & $36,72 \mathrm{bc}$ \\
\hline P1I1 & $22,05 \mathrm{a}$ & $32,00 \mathrm{cde}$ & $37,00 \mathrm{de}$ & $37,57 \mathrm{de}$ \\
\hline P1I2 & $22,62 \mathrm{a}$ & $30,28 \mathrm{a}$ & $33,95 \mathrm{a}$ & $34,65 \mathrm{a}$ \\
\hline P1I3 & $22,18 \mathrm{a}$ & $32,51 \mathrm{e}$ & $37,85 \mathrm{f}$ & $38,02 \mathrm{e}$ \\
\hline P2I1 & $22,82 \mathrm{a}$ & $34,49 \mathrm{ij}$ & $40,42 \mathrm{klm}$ & $40,50 \mathrm{ijk}$ \\
\hline P2I2 & $24,67 \mathrm{bc}$ & $32,33 \mathrm{de}$ & $37,33 \mathrm{ef}$ & $37,43 \mathrm{cde}$ \\
\hline P2I3 & $24,90 \mathrm{c}$ & $34,90 \mathrm{jk}$ & $38,90 \mathrm{ghi}$ & $39,13 \mathrm{fgh}$ \\
\hline P3I1 & $26,56 \mathrm{de}$ & $35,56 \mathrm{~lm}$ & $40,92 \mathrm{mn}$ & $41,54 \mathrm{mn}$ \\
\hline P3I2 & $26,67 \mathrm{ef}$ & $33,67 \mathrm{~g}$ & $39,00 \mathrm{hi}$ & $39,57 \mathrm{gh}$ \\
\hline P3I3 & $27,87 \mathrm{~g}$ & $33,54 \mathrm{fg}$ & $39,54 \mathrm{ij}$ & $39,89 \mathrm{hijk}$ \\
\hline P4I1 & $32,51 \mathrm{i}$ & $35,85 \mathrm{mn}$ & $40,58 \mathrm{lmn}$ & $40,65 \mathrm{kl}$ \\
\hline P4I2 & $27,77 \mathrm{fg}$ & $34,44 \mathrm{hij}$ & $40,10 \mathrm{jklm}$ & $40,52 \mathrm{jk}$ \\
\hline P4I3 & $29,92 \mathrm{~h}$ & $35,26 \mathrm{klm}$ & $41,26 \mathrm{no}$ & $41,33 \mathrm{lmn}$ \\
\hline LSD & $32,70 \mathrm{j}$ & $36,36 \mathrm{n}$ & $42,03 \mathrm{o}$ & $42,07 \mathrm{n}$ \\
\hline
\end{tabular}

Description: Numbers are accompanied by the same letters in the same column are not significantly different shows based on test $\mathrm{BNT} 5 \%$; WAP $=$ weeks after planting.

$\mathrm{P} 0=$ control; $\mathrm{P} 1=5 \mathrm{ml} / \mathrm{l} ; \mathrm{P} 2=10 \mathrm{ml} / \mathrm{l} ; \mathrm{P} 3=15 \mathrm{ml} / \mathrm{l} ; \mathrm{P} 4=20 \mathrm{ml} / \mathrm{l} ; \mathrm{I} 1$ = one application once a week; I2 = Two weeks once application; $\mathrm{I} 3=$ Three weeks once application. 


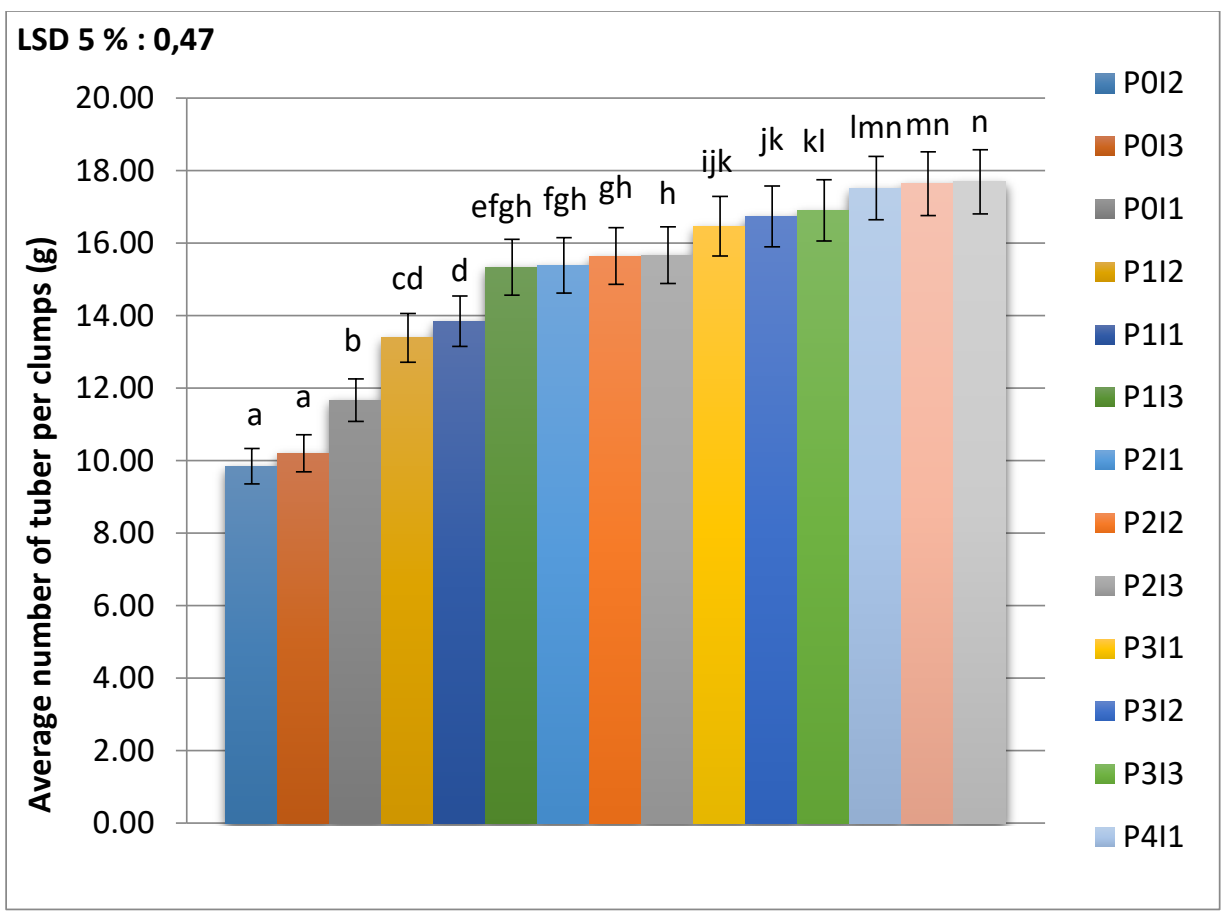

Description: $\mathrm{P} 0=$ control; $\mathrm{P} 1=5 \mathrm{ml} / \mathrm{l} ; \mathrm{P} 2=10 \mathrm{ml} / \mathrm{l} ; \mathrm{P} 3=15 \mathrm{ml} / \mathrm{l} ; \mathrm{P} 4=20 \mathrm{ml} / \mathrm{l}$; $\mathrm{I} 1$ = one application once a week; I2 = Two weeks once application; I3 = Three weeks once application.

Figure 1: Results of onion bulbs per panicle

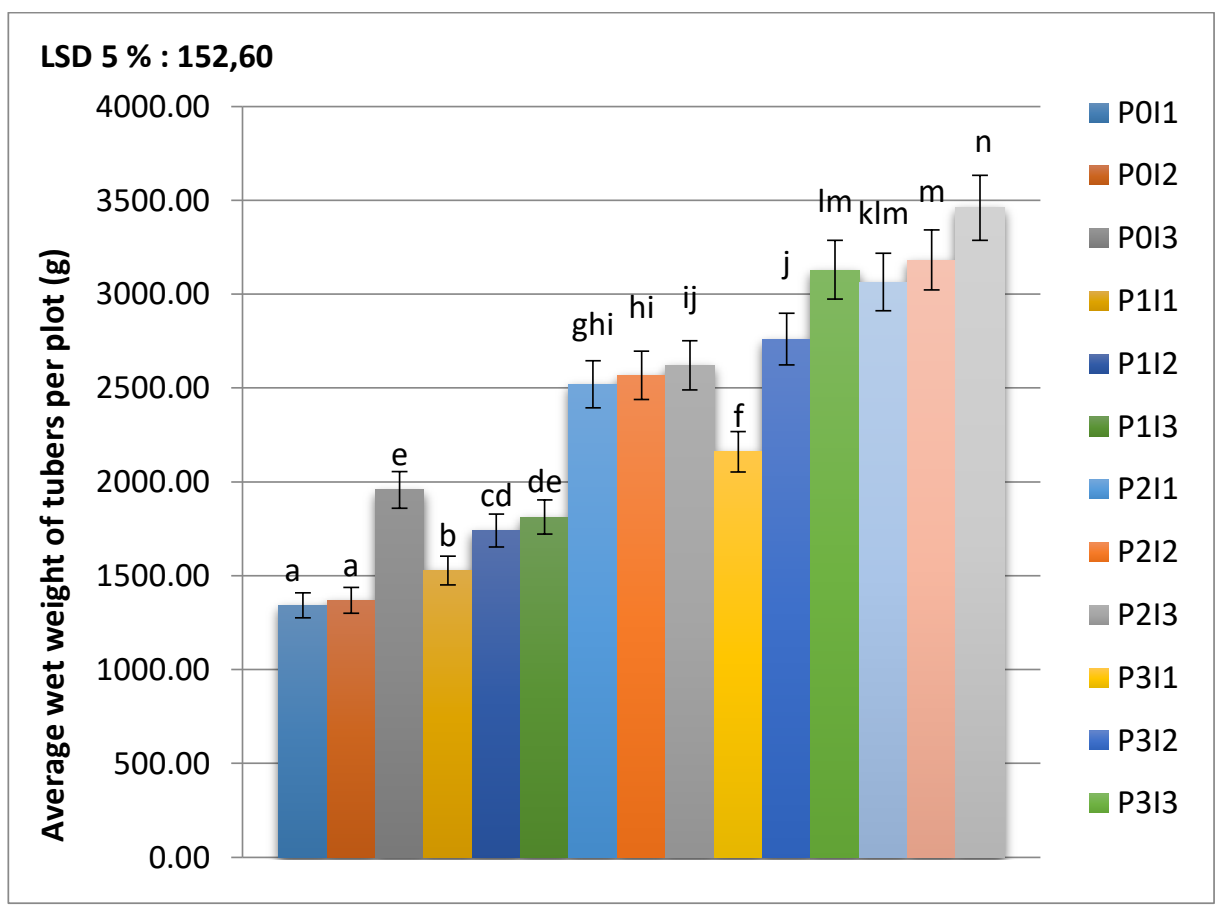

Description: $\mathrm{P} 0=$ control; $\mathrm{P} 1=5 \mathrm{ml} / \mathrm{l} ; \mathrm{P} 2=10 \mathrm{ml} / \mathrm{l} ; \mathrm{P} 3=15 \mathrm{ml} / \mathrm{l} ; \mathrm{P} 4=20 \mathrm{ml} / \mathrm{l}$; $\mathrm{I} 1=$ one application once a week; I2 = Two weeks once application; I3 = Three weeks once application.

Figure 2: Weight Wet tubers per plot 


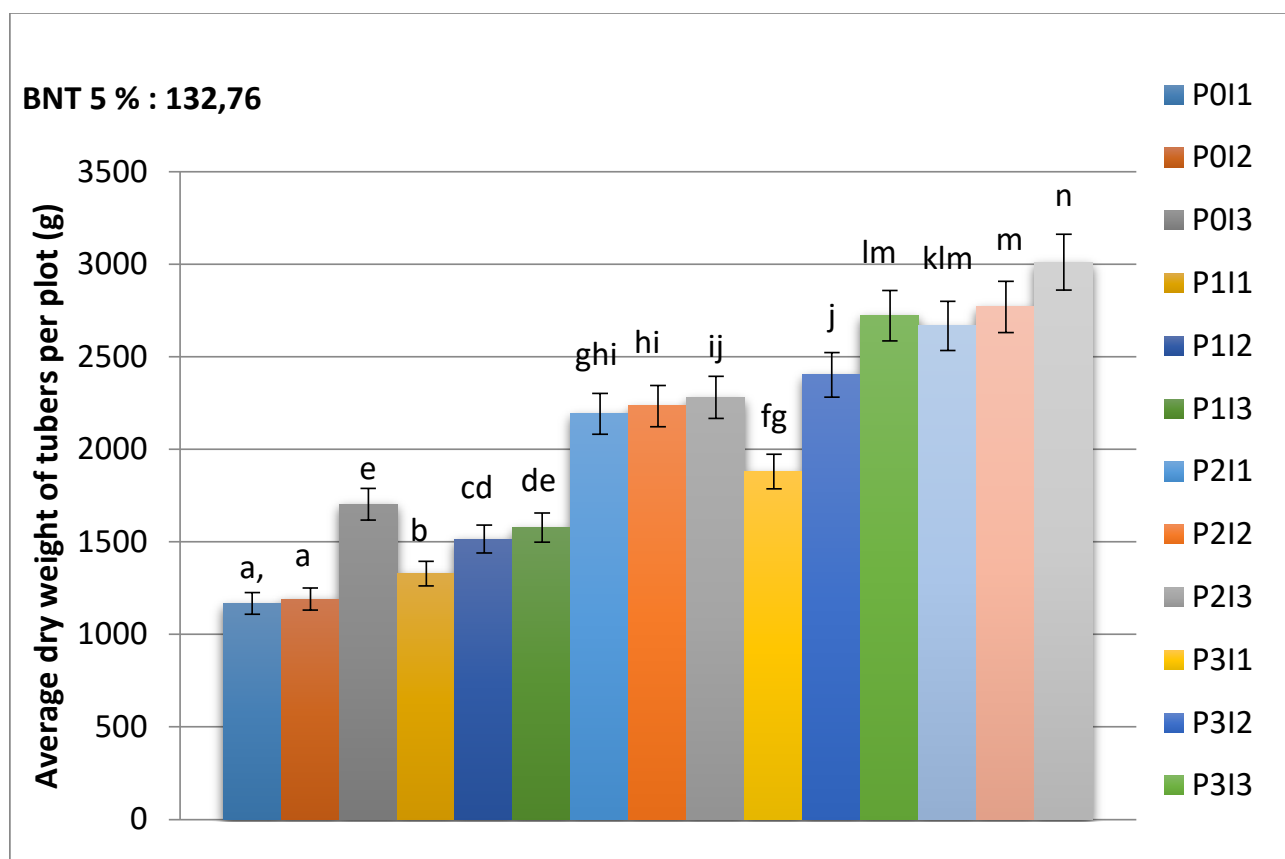

Description: $\mathrm{P} 0=$ control; $\mathrm{P} 1=5 \mathrm{ml} / \mathrm{l} ; \mathrm{P} 2=10 \mathrm{ml} / \mathrm{l} ; \mathrm{P} 3=15 \mathrm{ml} / \mathrm{l} ; \mathrm{P} 4=20 \mathrm{ml} / \mathrm{l}$; $\mathrm{I} 1=$ one application once a week; I2 = Two weeks once application; $\mathrm{I} 3=$ Three weeks once application.

Figure 3: Dry Weight Per plot Bulbs

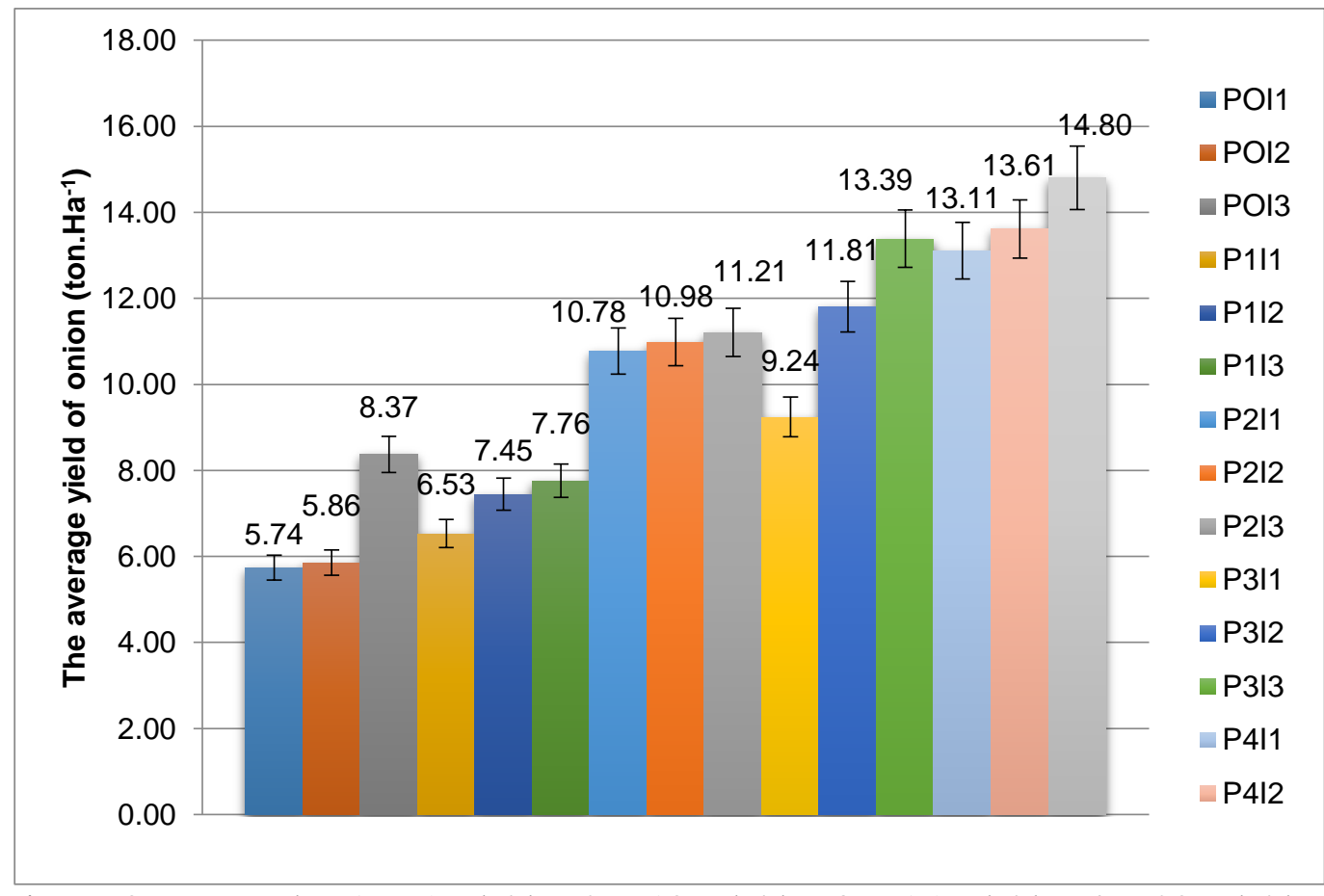

Description: $\mathrm{P} 0=$ control; $\mathrm{P} 1=5 \mathrm{ml} / 1$; P2 = $10 \mathrm{ml} / 1$; P3 = $15 \mathrm{ml} / \mathrm{l} ; \mathrm{P} 4=20 \mathrm{ml} / \mathrm{l}$; $\mathrm{I} 1$ = one application once a week; I2 = Two weeks once application; I3 = Three weeks once application.

Figure 4: Results Bulbs Per Hectare 


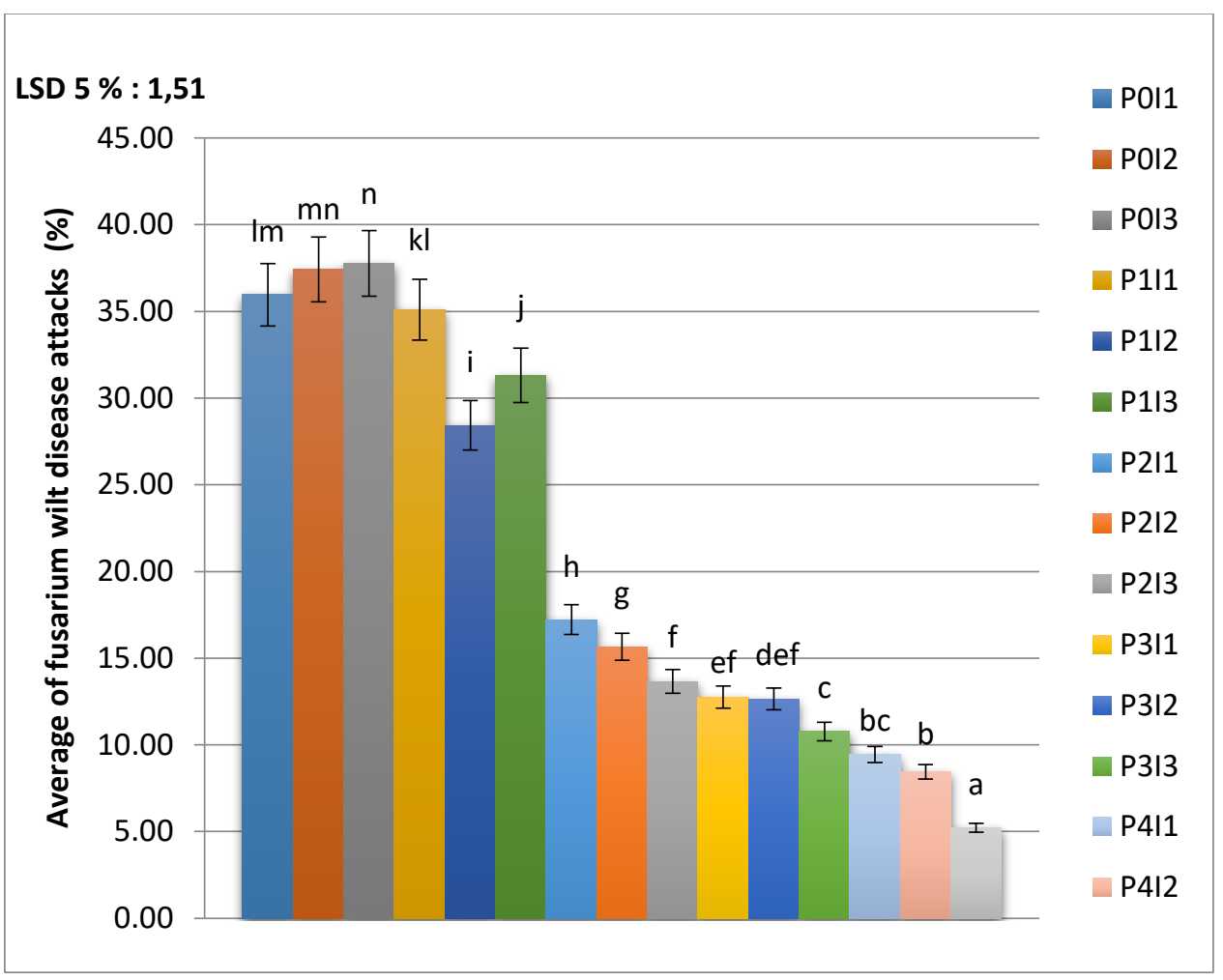

Description: $\mathrm{P} 0=$ control; $\mathrm{P} 1=5 \mathrm{ml} / \mathrm{l} ; \mathrm{P} 2=10 \mathrm{ml} / \mathrm{l} ; \mathrm{P} 3=15 \mathrm{ml} / \mathrm{l} ; \mathrm{P} 4=20 \mathrm{ml} / \mathrm{l} ; \mathrm{I} 1=$ one application once a week; I2 = Two weeks once application; 13 = Three weeks once application.

Figure 5: Percentage ofdisease attacks Fusarium wilt

\section{Discussion}

Plant growth process is controlled by two factors, namely internal factors (genetic and hormonal) and external factors (environmental grow plants). Growth onion plants have responded differently to PGPR concentration and administration time interval. It is suspected that genetic factors as well as the amount of PGPR concentration and administration time interval spur plant growth components higher than without the provision of PGPR. Wachjadi (2013) states that genetic factors are more dominant on the characters displayed plant for genetic factors contribute greater than environmental factors. Plants that have a high genetic diversity will greatly help a population to adapt to the changes occurring in the surrounding environment (Lehar, 2012). Giving PGPR directly into the soil allegedly capable Pendergrass organic matter in the soil at the same time the organic material becomes food for microorganisms to reproduce themselves. Lehar et al., (2016) state that plants treated with PGPR which there are biological agents T.viride, P.fluorescens, and Streptomyces sp, is able to decompose lignin, cellulose, and kithin of organic materials into food and provide nutrients are ready to be absorbed by plants. The organic material by microorganisms able to reproduce itself in accordance with the conditions of the organic material. This is in line by Lehar opinion, (2012) states that biological agents are given to organic fertilizer will be able to act as decomposers of organic matter and reproduce itself in such organic materials as well as providing nutrients to support plant growth. 
Giving PGPR function as decomposers of organic material and PGPR is able to stimulate the growth of the root system of plants and fungi hamper harmful bacteria. Lehar et al., (2016) and Rosyida et al., (2013) stated that the decomposed organic matter biological agents T.viride and combined with P. fluorescent and Streptomyces sp, as well as PGPR is able to stimulate high, the number of stems, number of leaves and leaf area plant. Ningrum et al., (2017) and Hollywood and Nehra (2011) suggested that the administration of PGPR on plant capable of replacing chemical fertilizers, pesticides and hormones that can be used in plant growth so as to increase, plant height, root length and dry weight of plants.

PGPR Award allegedly capable mengkloni per Karan plant roots so that the plant can absorb nutrients freely available that tersedi soil. Ningrum et al., (2017) stated that the administration of active PGPR colonize plant roots by having three main roles for the plant is as biofertilizer, biostimulant, and bioprotectants. PGPR is able to function properly if the availability sufficient organic matter as nutrients for PGPR so that the microorganisms in the PGPR is able to survive in the rhizosphere environment and perform its functions (Widyati, 2013). Giving PGPR can increase metabolic processes in the body of the plant, in line with the opinion of Saharan and Nehra (2011) which states that the metabolic processes in the plant body to function normally when microorganisms in PGPR can multiply inorganic materials and the availability of enough nutrients thereby affecting the process of photosynthesis and respiration.

Wet weight of tuber per plot highest in P4I3 treatment and the lowest for the treatment or there is a difference P0I1 $2117.67 \mathrm{~g}$. The high plant fresh weight per plot on P4I3 treatment allegedly because the role of PGPR to stimulate plant growth besides being able to suppress the pathogen. Gholami (2009) Declare that the granting of PGPR produces siderophores, antimicrobial compounds, and growth hormones, so as to stimulate plant growth. The granting of PGPR is able to improve plant growth and increase the weight of the wet and dry weight of plants and weight of tubers per hectare. This is in line with the results of the research of Mary (2010) which showed that PGPR generally can produce pepper fruit weight and weight per hectare which is higher than that of the untreated PGPR pepper plants. Khalimi and Gnas. (2009) states that the granting of significantly PGPR is able to increase the maximum plant height, number of branches of the maximum, the maximum number of leaves, fresh weight and dry weight of plant seeds and soybeans.

Plants that colonize the microorganisms present in the PGPR antagonistic against a pathogen can induce resistance response in plants. PGPR generally have a system response resistance in plants because it can produce some of the phenols which can be used to produce pathogen so as to provide a plant's immune to a disease (Rosyida et al., (2013). This is consistent with the results of the study (Susanto et al., 2013; Susanto et al., 2012; Sari et al., 2012; Chamzurni et al., 2011; Alfizar et al., 2011; Susanto et al., 2010) which states that the biological agent is able to suppress the pathogen so that plants can grow and develop without the attack of pathogens and as a producer of growth hormone or known as plant growth Promoting Rhizobacteria (PGPR), which can stimulate the growth of plants.

According to Wachjadi et al., (2013) stated that the content of phenolic compounds in plants is directly related to the level of plant resistance to infectious disease. Granting that PGPR contained in the biological agents T. viride and combined with P. fluorescent and Streptomyces 
sp able to control the disease fusarium wilt and Ralstoniasolanacearum, it is supported by the opinion Lehar et al., (2016), Hidayat et al., (2013) and Suprapta, (2012) which states that the granting of PGPR which there are biological agents biological agents P. fluorescence capable of controlling the disease fusarium wilt and Ralstonia solanacearum and other pathogenic fungi in potato plants. The results showed that the application of PGPR can reduce the intensity of the disease curling up to $61.20 \%$ and the intensity of P. capsici can be reduced to $47.79 \%$ (Mustikawati, 2014).

HCN compounds are secondary metabolites, which are generally produced by the bacterium $\mathrm{P}$. fluorescens and toxic to the fungal pathogen (Lehar et al.2016). PGPR indication of the mechanism of action to support plant growth is at the time of the strains of bacteria promoting growth indirectly by altering the balance of microbes in the rhizosphere. HCN, antibiotic compounds, chelating siderophores produced by some PGPR Feyang associated with its ability to reduce plant pathogens and toxic rhizobacteria (Salamiah and Wahdah, 2015). PGPR utilized in life processes of bacteria and as a support in doing activities that suppress the growth of pathogenic bacteria that attack plants (Diarta et al., 2016; Febriyanti et al., 2015; Hidayat et al, 2013; Ashrafuzzaman, 2009).

\section{Conclusion}

onion plants by PGPR could increase plant height $(21.67 \mathrm{~cm})$, number of leaves $(32.70)$, the number of tubers per hill $(17.69 \mathrm{~g})$, the wet weight of tuber per plot highs $(3460.00 \mathrm{~g})$ and dry weight of tuber per plot (3010.20 g) Results of tuber per hectare (14.80ton.Ha.1).Giving PGPR can control fusarium wilt on red onions. The higher concentration of PGPR with intervals of 3 weeks administration can suppress disease. Fusarium wiltPGPR concentration of $20 \mathrm{ml} / \mathrm{liter}$ of water with intervals of 3 weeks administration can suppress disease attacks fusarium wilt the lowest $(5.22 \%)$.

\section{Acknowledgment}

The authors would like to thank the Ministry of Education of East Timor that have financed the author to continue his studies at the University of Brawijaya Indonesia.

\section{References}

[1] Alfizar, Marlina, N. Hasanah. 2011. Upaya Pengendalian Penyakit Layu Fusarium Oxysporum Dengan Pemanfaatan Agen Hayati Cendawan Fma dan Trichoderma Harzianum. Journal Floratek (6): $8-17$.

[2] Ashrafuzzaman. 2009. Efficiency of Plant Growth Promoting Rhizobacteria (PGPR) for the Enhancement of Rice Growth. African Journal of Biotechnology 8(7):1247-1252.

[3] Badan Pusat Statistik. 2014. Luas Panen, Produksi, dan Produktivitas Bawang Merah 2009-2013. http://www.bps.go.id ( diakses 20 Maret 2017).

[4] Chamzurni, T., R. Sriwati, and R.D. Selian. 2011. Efektivitas Dosis dan Waktu Aplikasi Trichoderma virens terhadap Serangan Sclerotium rolfsi pada Kedelai. Jurnal Floratek, 6 (1): 6273.

[5] Choiruddin M R. 2010. Virulensi dan keanekaragaman genetika Fusarium oxysporum f. sp. cepae penyebab busuk pangkal pada bawang putih (skripsi) Surakarta (ID): Universitas Sebelas Maret. 
[6] Diarta I. M, C. Javandira, I. K. Widnyana. 2016. Antagonistik Bakteri Pseudomonas spp. Dan Bacillus spp. Terhadap Jamur Fusarium oxysporum Penyebab Penyakit Layu Tanaman Tomat. Jurnal Bakti Saraswati. 5(1):70-76.

[7] Esfahani M.N, Hossaini M, Ashrafi N. 2012. Screening of Iranian onion seed sets genotypes for resistance to Fusarium oxysporum f. sp. cepae. Intl J Farm Alli Sci. 1(1):9-15.

[8] Febriyanti L.E, Mintarto M, Tutung H. 2015. Pengaruh Plant Growth Promoting Rhizobacteria (PGPR) Terhadap Infeksi Peanut Stripe Virus (PStV), Pertumbuhan dan Produksi Tanaman Kacang Tanah (Arachis hypogaea L.) Varietas Gajah. Jurnal HPT. Vol. 3 (1): 84-92.

[9] Gholami, A., S. Shahsavani. and S. Nezrat. 2009. The Effect of Plant Growth Promoting Rhizobacteria (PGPR) on Germination, Seedling Growth and Yield of Maize. Proceedings of World Academy of Science, Engineerring and Technology. 3(7):19-24.

[10] Hidayat. C., Dedeh. H,. Arief, Nurbity.A,. Sauman.J. 2013. Inokulasi Fungsi Mikoroza Arnuskula dan mycorrhiza helper bacteria pada Andisol yang Diberi Bahan Organik utuk Meningkatkan Stabilitas Agregat Tanah, Serapan N dan P dan Hasil Taaman Kentang. Indonesian Journal of Applied Science. 3(2):26-41.

[11] Isniah U. S dan Widodo. 2015. Eksplorasi Fusarium Nonpatogen untuk Pengendalian Penyakit Busuk Pangkal pada Bawang Merah. Jurnal Fitopatologi Indonesia. 11(1):14-22

[12] Khalimi K \& W. Gnas. 2009. Pemanfaatan Plant Growth Promoting Rhizobacteria untuk biostimulants dan bioprotectants. Ecotrophic 4(2):. 131-135.

[13] Lehar L., 2012. Pertumbuhan kentang (Solanum tuberosum L.) di dataran medium akibat perlakuan pupuk organik dan tricoderma sp. Jurnal Biotropical Sains, Jurnal Biologi FST UNDANA. 9(2):57-67.

[14] Lehar L., T. Wardiyati, M. D. Maghfoer, A. Suryanto. 2016. Selection of potato varieties (Solanum tuberosum L.) in midlands and the effect of using biological agents. International Journal of Biosciences. 9(3): 129-138.http://dx.doi.org/10.12692/ijb/9.3.129-138.

[15] Maria, S. 2010. Pengaruh Aplikasi Bakteri Perakaran Pemacu Pertumbuhan Tanaman pada Tiga Genotipe Cabai (Capsicum annum L.) terhadap Pertumbuhan Tanaman serta Kejadian Penyakit Penting Cabai.. (skripsi).Jurusan Hama dan Penyakit Tumbuhan Fakultas Pertanian Institut Pertanian Bogor. Bogor

[16] Mustikawati. D.R. 2017. Effect of Plant Growth Promoting Rhizobacteria (pgpr) and Liquid Smoke against Diseases Attacks and Growth of Pepper (Piper nigrum L.). International Journal of Sciences: Basic and Applied Research 31( 3):145-155.

[17] Ningrum W.A, Karuniawan P.Wicaksono dan S. Y. Tyasmoro. 2017. Pengaruh Plant Growth Promoting Rhizobacteria (Pgpr) Dan Pupuk Kandang Kelinci Terhadap Pertumbuhan Dan Produksi Tanaman Jagung Manis (Zea mays saccharata) Jurnal Produksi Tanaman 5 (3): 433 440.

[18] Rosyidah A, Tatik Wardiyati and M. Dawam Magfoer. 2013. Enhancement in effectiveness of antagonistic microbe by means of microbial combination to control Ralstonia solanacea-rum on potato planted in middle latitude. AGRIVITA Vol.35/ No.2.

[19] Rosyidah A, Tatik Wardiyati and M. Dawam Magfur. 2014. Induced resistance of potato (Solanum tuberosum L.) to Ralstonia solanacearum disease with combination of several biocontrol microbes. Journal of Bio-logy, Agri-culture and Healthcare Vol.4/ No.2.

[20] Rusono N, Suanri A, Candradijaya A, Muharam A, Martino I, Tejaningsih, Hadi PU, Susilowati SH, Maulana M. 2013. Rencana Pembangunan Jangka Menengah Nasional (RPJMN) Bidang Pangan dan Pertanian 2015-2019. Jakarta (ID): Direktorat Pangan dan Pertanian, Bappenas.

[21] Sari N. M, R. Kawuri, K. Khalimi. 2012. Streptomyces sp. Sebagai Biofungisida Patogen Fusarium oxysporum(Schlecht.) f.sp. lycopersici (Sacc.) Snyd. et Hans. Penyebab Penyakit LayuPada Tanaman Tomat (Solanum lycopersicum L.)AGROTROP, 2(2): 161-169.

[22] Saharan, B.S. and V. Nehra. 2011. Plant Growth Promoting Rhizobacteria: ACritical Review. Life Sciences and Medicine Reseacrh 2(1):21-30. 
[23] Salamiah dan R. Wahdah. 2015. Pemanfaatan Plant Growth Promoting Rhizobacteria (PGPR) dalam pengendalian penyakit tungro pada padi lokal Kalimantan Selatan. Pros Sem Nas Masy Biodiv Indon 1(6): 1448-1456 DOI: 10.13057/psnmbi/m010632.

[24] Soesanto, L., E. Mugiastuti, and R.F Rahayuniati. 2010. Kajian Mekanisme Antagonis Pseudomonas fluorescens P60 terhadap Fusarium oxysporum f.sp. lycopersici pada Tanaman Tomat In Vivo. Jurnal HPT Tropika, 10 (2): 108-115.

[25] Soesanto L, Mugiastuti E, Rahayuniati RF.2012. Kajian mekanisme antagonis Pseudomonas fluorescens P60 terhadap Fusarium oxysporumf. sp. lycopersici pada tanaman tomat In Vivo. Jurnal Hama dan Penyakit Tumbuhan Tropika 10(2), 108-115.

[26] Soesanto, L., E. Mugiastuti, A. Manan, and M. Wachjadi. 2013. Ability test of several antagonists to control potato bacterial wilt in the field. Agrivita, 35 (1): 30-35.

[27] Suriani, N. 2011. Bawang Untung. Budidaya Bawang Merah. Cahaya Atma Pustaka. Yogjakarta.

[28] Suprapta DN. 2012. Potential of microbial antagonist as biocontrol agents against plant fungal pathogens. International Society for South east Asian Agricultural Sciences (18):1-8.

[29] Turkkan M, Erper I. 2014. Evaluation of anti-fungal activity of sodium salts against onion basal rot caused by Fusarium oxysporum f. sp. cepae. Plant Protect Sci. 50(1):19-25.

[30] Wachjadi, M., L. Soesanto, A. Manan, and E. Mugiastuti 2013. Pengujian Kemampuan Mikroba Antagonis Untuk Mengendalikan Penyakit Hawar Daun Dan Layu Bakteri Pada Tanaman Kentang Di Daerah Endemis. Jurnal Agroindustri, 17 (2): 92-102.

[31] Widyati, E. 2013. Dinamika Komunitas Mikroba di Rizosfir dan Kontribusinya Terhadap Pertumbuhan Tanaman Hutan. Tekno Hutan Tanaman 6(2):55-64.

\footnotetext{
*Corresponding author.

E-mail address: laurensius1@ yahoo.co.id
} 